\title{
China's Air Defence Identification Zone: Towards the Crystallization of a New International Custom
}

\author{
Matthias Vanhullebusch*
}

The establishment of China's Air Defence Identification Zone (ADIZ) above the East China Sea in November 2013 has triggered many questions as to its legality under international law, including the law on the use of force, aviation law and the law of the sea. ${ }^{1}$ Under the latter framework, the law has been ambivalent and has resulted in two distinctive practices in favour of the freedom of overflight on the one hand and the residual rights thesis on the other hand. A divergence persists in respect of the ADIzs that are established by developed and developing nations. Such division may prove to be an important factor for China to leverage support for its ADIZ in this grey area of international law. The common right to development of developing countries, which is tied to their respective exclusive economic zone (EEZ), can be a convincing argument for China to engage with these countries to secure their economic growth.

Furthermore, such potential support of numerous developing countries goes beyond China's foreign and security policies in the East China Sea. Their support can result in the crystallization of a new international custom in the long-term, namely one that constrains the freedom of overflight above the EEZ

* Associate Professor of Law, Executive Director of the Asian Law Center, KoGuan Law School, Shanghai Jiao Tong University (PhD, School of Oriental and African Studies, University of London); Series Editor of Brill's Asian Law Series and the Routledge Studies on Asia in the World. Contact: matthias.vanhullebusch@gmail.com.

1 Jaemin Lee, China's Declaration of an Air Defense Identification Zone in the East China Sea: Implications for Public International Law, 18 Proceedings of the American Society of International LaW (2014); Jae Woon Lee, Tension on the Air: The Air Defense Identification Zones on the East China Sea, 7 Journal of EAst Asia ANd International LaW 274 (2014); Jinyuan Su, The East China Sea Air Defense Identification Zone and International Law, 14 Chinese Journal of International Law 271 (2015); Matthias Vanhullebusch and Wei Shen, China's Air Defence Identification Zone: Building Security through Lawfare, 16 The China Review: An Interdisciplinary Journal on Greater China 121 (2016); Suk Kyoon Kim, Maritime Disputes in Northeast Asia: Regional Challenges AND COOPERATION 63-64 (2017).

(C) MATthiAs VANHULlEBUSCH, 2019 | DOI:10.1163/9789004379633_014

This is an open access article distributed under the terms of the prevailing CC-BY-NC License at the time of publication. 
when the coastal State extends its jurisdiction in the airspace above its EEz instead. This note will examine two different practices that can crystalize into a new international custom favouring the freedom of overflight (Section 2) or the residual rights thesis (Section 3). Consecutively, it will explore the conditions that are necessary to increase the normative basis of an emerging custom advanced by China (Section 4). It will make use of the Theory on the Relational Normativity of International Law (TORNIL) that argues that norms, values and relationships are interdependent sources from which an international custom (in the making) derives its binding force. ${ }^{2}$ From the perspective of relational governance, China will seek to manage its relationships with other (developing) countries in such a manner to draw support in defence of its own ADIZ practice and away from the other one.

\section{Practice One: ADIZ and the Communitarian Freedom of Overflight}

According to the (Chicago) Convention on International Civil Aviation, an ADIZ is a "special designated airspace of defined dimensions within which aircraft are required to comply with special identification and/or reporting procedures additional to those related to the provision of air traffic services". ${ }^{3}$ The Rules of Air adopted by the Council the International Civil Aviation Organization (ICAO) empower States to request compliance with "the rules and regulations relating to the flight and manoeuver of aircraft there in force" - even above the high seas. ${ }^{4}$ Pursuant to the law of the sea, such measures have to balance with the communitarian freedom of overflight enjoyed above the high seas as well as above the EEZ of the coastal State. ${ }^{5}$ Coastal States that establish an ADIZ above their EEZ must respect these freedoms as long as they are exercised peacefully ${ }^{6}$ and pay due regard to the other States' interests. ${ }^{7}$ Therefore, foreign aircraft - civilian

2 Matthias Vanhullebusch, Governing Asymmetries on the Battlefield:Towards a Relational Normativity, 9 Chinese Journal of International Politics 307, 318 (2016); Matthias Vanhullebusch, Global Governance, Conflict and China $5^{1}$ (2018).

3 Convention on International Civil Aviation, opened for signature 7 December 1944, 61 Stat. 1180, 15 UNTS 295 (entered into force 4 April 1947), Annex 15.

4 Ibid., Art. 12, annex 2, Rules of the Air, 2.1.1.

5 United Nations Convention on the Law of the Sea (UNCLOS), opened for signature Dec. 10, 1982, 21 I.L.M. 1261 (entered into force 16 November 1994), Arts. 87(1)(b), 58(1).

6 Art. 88, unCLOS.

7 Art. 87(2), UnCLOS. 
and military alike - of third States have to comply with those identification and reporting regulations adopted by the coastal State. ${ }^{8}$

The liberal perspective advanced by the U.s. acknowledges such equilibrium of communitarian and sovereign interests. However, it advocates that every nation has the right to exercise its freedom of overflight - especially for military purposes including surveillance - above the EEZ of the coastal State in a peaceful manner. ${ }^{9}$ As a result, it opposes the extended jurisdiction of the coastal State to regulate all (military) activities of third States in the airspace above its EEZ. It refutes the transplantation of the restrictive domestic regulations on the overflight of aircraft over the landmass and above the territorial sea of the coastal State to the entire airspace above the latter's EEz. ${ }^{10}$ Such encroaching jurisdiction renders the communitarian freedom of overflight as applicable above the high seas ${ }^{11}$ and enjoyed above the EEZ ${ }^{12}$ of a coastal State from the beginning obsolete. The actual nature of the EEZ, a suigeneris regime before the law of the sea, would, from this perspective, not justify extended jurisdiction on the basis of the sovereign rights that a coastal State exercises within its EEZ, namely related to the exploration and exploitation of living and non-living resources in the subsoil and the waters above. ${ }^{13}$

These nations favour the peaceful exercise of the freedom of overflight of aircraft above the EEZ of the coastal State, on the one hand, and the limited sovereignty of the coastal State to regulate such airspace, on the other hand. From this liberal perspective, at least eight countries have established such ADIzs that are currently still in force. Amongst those eight countries, six of them are developed (i.e., Canada, Japan, Norway, UK, US and South Korea) and two developing countries (i.e., India and Pakistan). Taiwan has also its own ADIZ that is still enforced and so had France and Italy respectively during the Algerian war for independence (1950s-196os) and Balkan Wars (1990s-200os). ${ }^{14}$

8 Art. 58(3), UNCLOS.

9 UN Doc. A/CONF.62/WS/37 (1983).

10 Art. 17, UNCLOS. Unlike aircraft, an innocent passage for ships is permitted within the territorial sea of the coastal State and does not require the latter's consent.

11 Art. 87(1)(b), UNCLOS.

12 Art. 58(2), UNCLOS.

13 Art. 56, unclos. See also Elizabeth Cuadra, Air Defense Identification Zones: Creeping Jurisdiction in the Airspace, 18 Virginia Journal of International LaW 485 (1978).

14 Peter A. Dutton, Caelum Liberam: Air Defense Identification Zones Outside Sovereign Airspace, 103 American Journal of International LaW 1, 10, 13, 17 (2009). 
Unlike the first ADIZ practice, other coastal States have argued that they have complete jurisdiction to regulate the airspace above their EEz. While UNCLOS defines explicitly the sovereign rights of the coastal State in its EEZ with particular reference to the economic exploitation and environmental protection of natural resources in the waters and subsoil thereof, ${ }^{15}$ it also includes "other rights and duties". ${ }^{6}$ Yet, the exercise of those sovereign residual rights including the regulation of military activities in the airspace above the coastal State's EEZ - must equally pay "due regard to the rights and duties of other States" - especially those who claim their peaceful freedom of overflight. ${ }^{17}$

Amongst those countries that accept the residual right thesis, 10 nations have official positions on their right to and/or domestic laws that regulate military activities in their EEz (i.e., Bangladesh, Brazil, China, India, Iran, Malaysia, Myanmar, North Korea, Pakistan and Uruguay). Five countries have actually asserted such right (i.e., Cape Verde, Kenya, the Maldives, Mauritius and Portugal). China and Guyana are the only countries that regulate all civilian and military overflight activities. ${ }^{18}$ As a result, at least seven countries have in fact exercised their residual rights in the EEZ - in the waters and/or airspace above. Amongst those countries, only one is a developed Western nation (i.e., Portugal).

IV

\section{Crystalizing a New International Custom: Towards a} Relational Normativity

Despite a scholarly view that all 168 countries who are a party to UNCLOS also adhere to the U.s. claim, ${ }^{19}$ there remains uncertainty if their membership to this treaty substitutes for their opinio juris in order to consolidate an international custom to that effect. In fact, the actual practice of a limited number of States supporting either practice (8 in favour of the freedom of overflight and 7 in favour of the residual rights thesis) may not represent a so-called "appreciable section of the international community" - as once observed in the context of the legality of nuclear weapons by the Chinese Judge Jiuyong Shi in

\footnotetext{
15 Art. 56(1)(a), UnCLOS.

16 Art. 56(1)(c), UNCLOS.

17 Art. 56(2), UNCLOS.

18 Dutton, supra note 14 , at 7.

19 Ibid., at 7. Dutton, however, only supports this claim on the basis of the number of parties to UNCLOS.
} 
the ICJ's Nuclear Weapons advisory opinion. In this respect, he continued that the limited practice and "material power" of nuclear weapons States might not constitute the foundation to establish an international custom on the use of such weapons since that would violate the principle of sovereign equality. ${ }^{20}$

Nonetheless, in the absence of greater participation of States in support of either practice of ADIZs, leading States - the US and China in particular have sought to turn their positions and interests into customary international law. In the present study of China's ADIZ, it is therefore necessary to identify the techniques which China has pursued to advance its normative practice through military, economic and diplomatic strategies. ${ }^{21}$ The U.s. Department of Defense reported as early as 2007 that Chinese "military strategists have taken an increasing interest in international law as an instrument to deter adversaries prior to combat" and that China "is shaping international opinion in favor of a distorted interpretation of the UN Convention on the Law of the Sea by moving scholarly opinion and national perspectives away from long-accepted norms of freedom of navigation and toward interpretations of increased sovereign authority over the EEZ, the airspace above it". ${ }^{22}$

China's legal strategy, however, goes beyond such mere lawfare. ${ }^{23}$ In addition, its relational governance aims at instilling trust through a long-term process of negotiating political and security arrangements between the participants on the international plane (globally and regionally alike) to reach a synthesis on their initial opposing interests. ${ }^{24}$ So far, in 2014, China and the U.S. have reached a Memorandum of Understanding to avoid potential conflicts between both militaries though they did not reach an agreement regarding their fundamental divergent interpretations on the law of the sea. ${ }^{25}$ Regionally

$20 \quad$ Legality of the Threat or Use of Nuclear Weapons, 1996 I.C.J. Reports 226 (July 8) (Declaration of Judge Jiuyong Shi).

21 Stanley Hoffmann, The Study of International Law and the Theory of International Relations, 57 Proceedings of the American Society of International Law 26 (1963).

22 U.s. Department of Defense, Annual Report to Congress on the Military Power of the People's Republic of China 2007, available at http://www.defense.gov/pubs/pdfs/070523-China -Military-Power-final.pdf, at 13.

23 Ibid.; Eric Heginbotham, China's ADIZ in the East China Sea, LAWFARE BLOG, available at http://www.lawfareblog.com/2014/o8/the-foreign-policy-essay-chinasadiz-in-the-east -china-sea/.

24 Yaqing Qin, Rule, Rules, and Relations: Towards a Synthetic Approach to Governance, 4 Chinese Journal of International Politics 133 (2011).

25 Memorandum of Understanding between the Department of Defense of the United States of America and the Ministry of National Defense of the People's Republic of China Regarding the Rules of Behavior for Safety of Air and Maritime Encounters (Washington, 9-10 November 2014). 
too, in 2017, China and ASEAN member States adopted the Framework for the Code of Conduct that could ensure more peace, prosperity and stability in the South China Sea. ${ }^{26}$ The latter departs from the earlier distrust that reigned amongst the conflicting littoral states on the South China Sea ever since the Philippines had initiated arbitral proceedings against China and after the negative arbitral outcome against it. ${ }^{27}$ Moreover, in 2017, India and Pakistan have joined the Shanghai Cooperation Organisation (sco), another regional security body headquartered in Beijing.

Such confidence-building measures could be a first step for China to realign support for its ADIZ practice - at least with a regional section of the international community in these other but more certain areas of (maritime) security governance. Also in the economic realm, all ASEAN coastal States as well as other countries, including Bangladesh, India, Iran and Pakistan, along the Maritime Silk Road have joined China's One Belt One Road (ОвоR) initiative and are members of its Asian Infrastructure Investment Bank (AIIB) since 2015. ${ }^{28}$ Each of these various security, economic and diplomatic forms of cooperation between China and other coastal member States bilaterally or within a regional setting - institutional (AIIB, ASEAN and SCO) and non-institutional (OBOR) alike - have a common denominator whose content is sufficiently shared by each partner: security and development. Both values are inextricably linked and have been the basis for (re)new(ed) cooperation between China and various Asian coastal nations (with the exception of Japan and South Korea). They underscore the rationale behind the practice of extended jurisdiction over the airspace above the EEZ of those nations whose economic development has

26 Christian Shepherd and Manuel Mogato, ASEAN, China Adopt Framework for Crafting Code on South China Sea, REUTERs, 6 August 2017, available at https://www.reuters.com/ article/us-asean-philippines-southchinasea-idUSKBNıAMoAY. The final adoption of the Code of Conduct as once envisaged in the Declaration on the Conduct of Parties in the South China Sea (Phnom Penh, 4 November 2002) aims to advance such common security and economic objectives.

27 The South China Sea Arbitration (The Republic of the Philippines v. The People's Republic of China), PCA Case No. 2013-19, Award (12 July 2016). See also Lowell Bautista, The Philippines and the Arbitral Tribunal's Award: A Sombre Victory and Uncertain Times Ahead, 38 Contemporary Southeast Asia 349 (2016).

28 People's Republic of China, Chinese National Development and Reform Commission, Ministry of Foreign Affairs, and Ministry of Commerce, Vision and Actions on Jointly Building Silk Road Economic Belt and 21st-Century Maritime Silk Road (Information Office of the State Council, March 2015); Matthias Vanhullebusch, China's Development Banks in Asia: A Human Rights Perspective, in Yumiko Nakanishi (ed.), CrossFertilization in Human Rights Law: European and Asian Perspectives 207 (2017). 
an intimate security component. Without security at sea and in the air, the economic prosperity of Asia's emerging economies would be compromised.

On the long-term and from the perspective of TORNIL, China's promotion of the sovereign right of the coastal State to deny access of overflight to civilian and military aircraft of third States in the airspace above its EEZ - pursuant to its own domestic regulations that called into being an ADIZ to that effect, relies on three interdependent sources. Firstly, the norm itself that finds its origin in the residual rights thesis defined in Article 56(1) of UNCLOS that has been supported by the practice of 7 States. Secondly, the values that underpin the exercise of such sovereign prerogatives, namely the right to (peaceful) development, that has been gradually internalised amongst the developing countries along the Maritime Silk Road. Thirdly, the various sets of harmonious relationships based on trust and reconciliation of opposing interests that provide the fertile soil in which such new international custom can gain root.

Here, China's relational governance does not only have to manage a convergence of expectations within those relationships - in particular with (Asian) developing coastal States - on the binding force of its ADIZ practice based on shared security and economic values on the one hand. It must also seek to engage with the US not necessarily to align its position with its own but avoid conflict that would inevitably compromise all of China's relationships within its neighbourhood and beyond - thus, denying the fertile soil. Yet, the U.s. global role to promote its version of the international rule of law is diminishing which leaves a vacuum that China can exploit to project its normative projects including but not limited to its ADIZ practice. ${ }^{29}$ In the long-term, China can convince more (Asian) developing coastal States to establish or readjust (in the case of India and Pakistan) their own ADIz following Chinese characteristics that can outweigh the number of supporters to the U.s. practice.

\section{Conclusion}

The crystallization of a new international custom in favour of extended jurisdiction of the coastal State over the airspace above its EEz to deny overflight activities - civilian and military alike - has met different challenges that more than ever has exposed a deep divide between developed and developing countries. China has sought indirectly to pull support of the former ADIZ practice through its relational governance, namely by establishing trustworthy

29 Endangered: American Influence Has Dwindled under Donald Trump. It Will Not Be Simple to Restore, The Economist, 11 November 2017. 
relationships with its allies and (former) enemies through economic and security cooperation. Regardless of the form of the latter's governance, it can provide a fertile soil for those coastal States - Asian developing countries in particular - to lend their support to China's ADIz model. Without their support, the residual rights thesis and the shared security and development values that underpin the emerging custom cannot give the new norm its binding force. Given the split practice amongst a small proportion of the members of the international community, reaching such common understanding will be difficult and fragile to sustain in particular as China would use the new (regional) custom to bolster its territorial claims in the disputed waters. 